\title{
Karstic behaviour of groundwater in the English Chalk
}

\author{
LD Maurice ${ }^{1}$, TC Atkinson ${ }^{1,3}$, JA Barker ${ }^{1}$, JP Bloomfield ${ }^{2}$, AR Farrant ${ }^{2}$, AT \\ Williams $^{2}$ \\ ${ }^{1}$ Department of Earth Sciences, University College London, UK \\ ${ }^{2}$ British Geological Survey, UK \\ ${ }^{3}$ Department of Geography, University College London, UK
}

\begin{abstract}
Although the Chalk is only weakly karstified, tracer testing from stream sinks has demonstrated groundwater flow velocities comparable to those observed in highly karstic aquifers. Field survey of surface karst features in the catchments of the Pang and Lambourn rivers in southern England demonstrates the importance of overlying and adjacent Palaeogene strata in the development of karst features. Tracer techniques employed within the catchments enable further characterisation of the range and connectivity of solutional voids in this area of the Chalk, and allow assessment of the relative importance of different mechanisms of contaminant attenuation. Quantitative tracer test results suggest that groundwater flow may be through a complex combination of small conduits, typically 10 to $1000 \mathrm{~mm}$ in diameter, and more laterally extensive fissures with apertures of 1 to $50 \mathrm{~mm}$. Evidence of connectivity between conduits and fissures suggest that in areas of the Chalk with rapid groundwater flow, fissures supplying abstraction boreholes may be connected to karst conduit networks with low potential for contaminant attenuation.
\end{abstract}

Keywords: Chalk; Karst; Groundwater; Tracer testing

\section{1) Introduction}

The hydrogeological conditions associated with karst involve very rapid flow velocities within extensive cave systems. However karst processes occur at a range of scales and in the English Chalk small scale karst geomorphological features such as dolines, stream sinks and dry valleys are commonly observed. Walsh and Ockenden (1982) give a detailed description of the geology of the largest stream sink complex in the Chalk at North Mimms, Hertfordshire. Additional evidence of the soluble nature of the Chalk is seen from subsurface sediment-filled dissolution pipes, which have been exposed by quarrying or engineering works, with densities of up to 265 per hectare (Lamont-Black, 1995). Recognition of surface karst features in the Chalk has led to groundwater tracing which has proved the existence of rapid flow between stream sinks and springs (Harold, 1937; Atkinson and Smith, 1974; Banks et al., 1995). Rapid groundwater flow is thought to be quite widespread in the Chalk (Macdonald et al., 1998), but the extent and nature of voids and pathways within which it occurs are still poorly understood.

The definition of terms relating to openings in rock that carry water is notoriously problematic (e.g. Bloomfield, 1995). As used in this paper the term 'fracture' may be defined purely geometrically as any planar discontinuity in the Chalk which has a finite aperture. Genetically they may originate as joints (tensional or shear) or small faults. Some fractures have been widened by solution, i.e. karstically modified, and these may be termed 'solutionally enlarged fractures', but for brevity and in line with common usage, we will synonymously use the term 'fissure'. Modifications may take 
the form of small channels on the fracture surfaces or of a general widening over a substantial proportion of the fracture area. They are distinguished from 'conduits' (see below) by the fact that they retain the generally planar geometry of unmodified fractures.

'Conduits' are tubular voids formed by solution which are distinguished from fissures by the aspect ratio they present in cross section which is $\sim 1$ in contrast to fissures which have trace length to maximum aperture ratios greatly in excess of 10 . For Chalk, we observe diameters $\sim 10 \mathrm{~mm}$ to $\sim 1000 \mathrm{~mm}$, and we infer lengths in the range of 10's of metres to several kilometres. The largest conduits, caves large enough for a human to enter, are rare in the English Chalk (Lowe, 1992 and references therein). The most significant Chalk cave in England is the $400 \mathrm{~m}$ long Beachy Head Cave, Sussex (Bradshaw et al., 1991; see also pages 282-283 in Waltham et al., 1997). In France and Belgium large Chalk caves are more common, and caves over a kilometre in length have been explored (Rodet, 1985; Waltham, 1975). Small conduits 50 to $300 \mathrm{~mm}$ in diameter can be observed in some cliff exposures and quarry faces in England (Figure 1), suggesting that the extent of small conduit development in the Chalk may have been underestimated. 'Dissolution tubules' is a term used by Lamont-Black and Mortimore (2000) for a specific type of conduit feature seen in road cuts and rapidly retreating sea cliffs in England. They are irregular bifurcating voids 1 to $50 \mathrm{~mm}$ in diameter, developed along specific stratigraphic or tectonic discontinuities. They are often laterally extensive over many hundreds of metres and result in localised rapid groundwater flow. These tubule horizons are often the foci for larger conduit development as at Beachy Head Cave.

Although the Chalk is the most important aquifer in England, the role of karst is usually neglected in water resource protection. Fissures are the commonest karstic features intercepted in boreholes. Where they are present they provide the major source of groundwater supply. The nature and connectivity of fissures and conduits, and their relationship with surface karst features is poorly understood. Studies in the highly karstic Carboniferous Limestone in the UK have proved interaction between cave conduits and fissures intercepted by quarrying (Edwards et al., 1991). Poor groundwater quality in some Chalk boreholes, in particular turbidity and bacteria (Macdonald et al., 1998), suggest that there may also be interaction between fissures and larger scale conduits in the Chalk. This paper will consider this question further with respect to the results of tracer testing, and use our current studies of the PangLambourn catchments as an example of the relationship between surface karst geomorphology and subsurface groundwater flow.

\section{2) Surface karst in the Pang and Lambourn}

The Pang and Lambourn catchments cover $400 \mathrm{~km}^{2}$ in Berkshire, southern England. The catchments are principally within the Seaford Chalk Formation, on the northern limb of the London Basin syncline. In the south of the area, the Chalk is overlain by clays and sands of Palaeogene age and superficial Clay-with-flints. Field survey of karst features has revealed three distinctive geomorphic 'Zones' in the Pang and Lambourn as indicated in Figure 2. These can be characterised by the density of surface karst features and are related to the proximity to the Palaeogene-Chalk contact. 
Karst is most extensive in the lower reaches of the catchments (Zone 1) where the Chalk is overlain by Palaeogene deposits, which produce acidic soils. Along the margin of the Palaeogene cover there are many dolines and a proportion of recharge to the Chalk occurs as allogenic point inputs. Stream sinks have developed on the edge of the Palaeogene cover where it is thin and composed of sands and gravels, allowing chemically aggressive infiltration to dissolve the underlying Chalk. Most stream sinks are fed by small springs issuing from the Palaeogene augmented by surface runoff and artificial drainage.

One hundred and twenty eight stream sinks in the catchments were observed in summer 2003 when around twenty five had very small flows $(0.01$ to $0.5 \mathrm{l} / \mathrm{s})$ but most were dry, indicating that they are often ephemeral features. Thirty seven were characterised by distinct channels ending at dolines with eroded holes in the base (large black circles on Figure 2), and many of these were observed during wetter periods during 2003/2004 and 2004/2005 winters to be providing more substantial flows of between 1 and 2 1/s. Repeated observation of a small number of stream sinks indicated that they respond very rapidly to rainfall. There are several Chalk springs in the river valleys in Zone 1, the largest being the Blue Pool with a discharge of around $2001 / s$.

In the middle reaches of the catchments (Zone 2), there are no stream sinks and recharge appears predominantly diffuse. This is the zone where the Palaeogene deposits have been most recently eroded and much of the area is overlain by Claywith-flints, providing a low permeability cap on the Chalk surface. On and around areas covered by Clay-with-flints there are hundreds of karst dolines which may focus recharge at shallow depths beneath the surface. In Zone 2 there are springs at the perennial heads of the Pang and Lambourn rivers, and upstream ephemeral springs which become active progressively in response to seasonal rise in groundwater levels. This type of river head migration to springs at specific points is characteristic of karst areas where the capacity of the conduit system is exceeded under high flow conditions resulting in re-activation of ephemeral conduits which are discharged through the ephemeral higher springs.

In the upper reaches of the catchments (Zone 3), Chalk is exposed at the surface with no cover or superficial deposits to concentrate drainage, and recharge is entirely diffuse. There is little evidence of surface karst except that the landscape is characterised by dry valleys and almost all drainage is subsurface.

\section{3) Tracer testing from Smithcroft Copse, Berkshire}

A previous tracer test from Holly Grove stream sink in Zone 1 to the Blue Pool (Figure 3), gave a groundwater velocity of $5.7 \mathrm{~km} / \mathrm{d}$ (to peak concentration) but mass balance was not reported (Banks et al., 1995). During the current study natural gradient tracer testing was conducted from a nearby site at Smithcroft Copse (Figure 3 ) to determine mass balance and investigate the nature of the active subsurface conduits in Zone 1 in more detail.

Two injections were made, of $92 \mathrm{~g}$ and $610 \mathrm{~g}$ of a fluorescein tracer. The tracer was a liquid product in which the active fluorescein component was $70 \%$. The stream at Smithcroft Copse sinks in a number of places over a length of several hundred metres. The position of the sink points was observed to vary from week to week as new 
depressions and small holes were eroded by the stream in the alluvium over which it was flowing. During the tracer testing the total flow was around 2-3 1/s. At the time of the first injection there was some degree of ponding in most areas where water was sinking. Tracer was poured into the only section of stream which was draining directly into a hole without any surface ponding, although only a small proportion of the total flow was sinking at this point. At the time of the second injection a new hole had been formed which was not ponded and drained a larger proportion of the flow, but for consistency the tracer was injected into the same point as the first injection, which was still not ponded.

The Blue Pool outlet channel was monitored in situ using a fluorometer and water samples were automatically collected at Ingle and Jewells springs (Figure 3). Two piezometers in a borehole on the north side of the River Pang were sampled using a small pump. Flow was gauged by current meter at the springs and at the River Pang downstream of all the springs on several occasions before and during the tracer test. River flow was monitored by frequent readings of a stage board at the downstream site. Both injections produced breakthrough curves at the Blue Pool outlet (Figure 4), and the results are summarised in Table 1.

Tracer recovery was calculated between each initial breakthrough and the return of tracer concentrations to below the detectable threshold. Groundwater velocities were similar to that $(5.7 \mathrm{~km} / \mathrm{d})$ obtained by Banks et al. (1995) in the tracer test from Holly Grove which was conducted using artificial recharge. The ratio of peak concentration to mass injected was twice as large during the first injection which took place under higher flow conditions. Tracer continued to be discharged at low concentrations for a week following the second injection. Tracer was not detected in the piezometers in the borehole to the north of the Pang where background fluorescence of $0.06 \mu \mathrm{g} / \mathrm{l}$ was notably lower than at the Blue Pool $(0.35 \mu \mathrm{g} / \mathrm{l})$ and the River Pang $(0.5 \mu \mathrm{g} / \mathrm{l})$ (Table 2).

No tracer was detected at Ingle or Jewells springs. Average background fluorescence of $0.2 \mu \mathrm{g} / \mathrm{l}$ at Ingle and $0.18 \mu \mathrm{g} / \mathrm{l}$ at Jewells was slightly lower than at the Blue Pool. These springs are considerably smaller than the Blue Pool with flows of $30 \mathrm{l} / \mathrm{s}$ and 20 $1 / \mathrm{s}$, respectively. Table 3 summarises the flow data $(1 / \mathrm{s})$ obtained by current meter during the tracer experiments. At the time of the tracer testing the Blue Pool discharge contributed approximately $60 \%$ of the total flow in the River Pang downstream of all the springs, whilst Jewells and Ingle springs had a combined contribution of about $15 \%$.

\section{4) Discussion}

\subsection{Groundwater flow and tracer transport in Zone 1}

Groundwater velocities determined from tracer tests to the Blue Pool are comparable to those found in highly karstic aquifers. Previous tracer tests from five sinks in the English Chalk in Hertfordshire and Hampshire demonstrated similar velocities of 2.2 to $5.8 \mathrm{~km} /$ day over distances of 4 to $19 \mathrm{~km}$ (Harold, 1937; Atkinson and Smith, 1974). Although these are not in the Pang-Lambourn, their location at the Palaeogene-Chalk boundary and general topographic situation place these sites in the equivalent of Zone 1. This suggests that in areas of the Chalk with Zone 1 surface karst characteristics, rapid groundwater flow with low potential for contaminant attenuation may be relatively common. However, we have made repeated attempts to trace another 
stream sink at Mirams Copse in Zone 1 of the Pang to the north of the Blue Pool (Figure 3) and, despite a comprehensive monitoring network, obtained entirely negative results under very low flow conditions. It is therefore possible that not all the stream sinks under all conditions are characterised by rapid flow along a fully connected conduit network.

Comparison with the mean annual discharge and catchment area for the River Lambourn reported by Grapes et al. (2005), suggests that assuming a mean discharge of $200 \mathrm{l} / \mathrm{s}$ at the Blue Pool, it may have a catchment area of roughly $30 \mathrm{~km}^{2}$, but the location of this catchment is still uncertain. Negative tracer results from the Mirams Copse sink to the north of the Blue Pool suggest that the catchment may not extend in this direction, although further tracer testing under higher flow conditions and from other stream sinks might determine this more conclusively. Tracer testing has demonstrated that the catchment extends $5.1 \mathrm{~km}$ west of the Blue Pool, and it is possible that the overall catchment comprises a thin wedge which extends further westwards towards the Lambourn catchment. It is also possible that some flow may be from the confined Chalk to the south of the Blue Pool, where there are no stream sinks present, but conduits and fissures may have developed beneath the Palaeogene cover.

Although there is no detailed spring hydrograph data for the Blue Pool to determine spring response to precipitation, flow data were collected on 15 occasions between 1976 and 1988 (Banks pers. comm., 2005) when discharge varied between 150 1/s $(05 / 08 / 76)$ and $2401 / \mathrm{s}(07 / 01 / 83)$. These limited data suggest that there is a large baseflow component to the Blue Pool, and that the proportion of flow derived from recharge through stream sinks may be quite small. This hypothesis is supported by observations of the stream sinks in the catchments. The Smithcroft Copse stream sink only contributes a very small proportion of flow to the Blue Pool (the flow in the sink was approximately 1-2 1/s at the time of the tracer test compared to the Blue Pool flow of $200 \mathrm{l} / \mathrm{s}$ ). The Blue Pool water cannot be derived exclusively from stream sinks, as even if all the stream sinks in both catchments were connected to the Blue Pool they do not provide sufficient flow. (A rough estimate for recharge from all stream sinks in Pang and Lambourn is 35 to $70 \mathrm{l} / \mathrm{s}$, following heavy or prolonged rainfall in winter, less than $10 \mathrm{l} / \mathrm{s}$ in dry periods). More importantly, most stream sinks only flow in winter. The large summer flow from the Blue Pool implies a significant additional source that flows more slowly but consistently throughout the year, and therefore the conduit system must be constantly recharged by water released from storage. One obvious location for such storage is the Chalk aquifer itself, but given the low drainable porosity of the Chalk it is feasible that drainage from perched groundwater bodies in the Palaeogene also contribute significantly.

It has been shown that groundwater velocities measured from tracer tests could result from flow through either small cave conduits or more laterally extensive fissures. For the Hampshire case study Atkinson and Smith (1974) calculated that, for the estimated head gradient, the volume indicated by the tracer time to peak was equivalent to flow in a single circular pipe of $740 \mathrm{~mm}$ diameter. Price (1987) calculated that a smooth planar fissure with an aperture of $4.5 \mathrm{~mm}$ provides an alternative hydraulic explanation for the observed combination of displacement volume and velocity. Using the same method Banks et al. (1995) calculated that a single fissure of $5.4 \mathrm{~mm}$ aperture could have transported the tracer from Holly Grove 
sink to the Blue Pool. Similarly, velocities from the current tracer test would suggest an aperture of $4.9 \mathrm{~mm}$. However, the hydraulic gradient (0.004) is calculated using the elevation difference between the sink and the spring, and since the water table is lower than the surface elevation of the stream sink, the actual hydraulic gradient must be smaller, and therefore the calculation must underestimate aperture.

Understanding the nature and connectivity of conduits and fissures is important because if the subsurface karst is characterised by discrete tubular conduits connecting stream sinks to springs, with little connectivity with fissures, there is less risk to groundwater abstraction boreholes, which are unlikely to intercept such a conduit, but high risk of water quality problems at springs. Conversely, if there is a high degree of connectivity between conduits and fissures, the risk of rapid transport of contaminants to groundwater abstractions may be high.

Visible colouration in the Blue Pool complex during our test proved that tracer was discharged at a number of sites up to $100 \mathrm{~m}$ apart which could imply flow through laterally extensive fissures in the vicinity of the springs. In the tracer test conducted by Atkinson and Smith (1974) in Hampshire, tracer was recovered at two groups of outlets with most of the recovered dye at one group and only $0.6 \%$ at the other. In the Water End tracer tests in Hertfordshire (Harold, 1937), visible colouration proved connections to 7 spring and borehole abstraction sites up to $6 \mathrm{~km}$ apart. These tracer tests suggest that in the downstream sections, the conduit systems are characterised by fissure flow causing lateral dispersion across a large scale 3-D network. The Water End study demonstrates conclusively that there can be connectivity between conduit systems and fissures supplying groundwater abstraction boreholes.

Qualitative interpretation of the recovery data and breakthrough curve from the Smithcroft Copse tracer test also suggests there may be a complex flowpath. Tracer recoveries of $25 \%$ and $21 \%$ from the present study and $70 \%$ from the Hampshire tracer tests (Atkinson and Smith, 1974) all indicate significant losses of tracer. This could be because tracer was discharged at an unmonitored outlet, but it is more likely that tracer was lost by mechanical dispersion or diffusion into the porous Chalk matrix during transport. The shape of the second breakthrough curve (Figure 4) displays a steep falling limb after the main peak, followed by a long flat tail of low concentration. Such a pattern is predictable from models in which channelled flow exchanges tracer with zones of static water by the mechanism of double porosity diffusion (e.g. Barker, 1982; Barker, 1991). However, the rapid travel time (about 1 day) implies that for a single conduit or fissure, tracer transport would be too rapid for double porosity diffusion to account for the tracer loss: the time for significant diffusional loss from a fissure of aperture $4.9 \mathrm{~mm}$ is of the order of 5 days.

A possible explanation for the loss of tracer is that some sections of the flowpath are characterised by multiple pathways with dispersion from the main conduit into smaller fissures and fractures. Whilst the breakthrough curve (Figure 4) with single peaks following each injection could be interpreted as indicative of a single pathway, peaks from multiple pathways could coalesce to form the observed breakthrough curve.

Recalling that monitoring was carried out downstream of the Blue Pool complex, there is potential for dispersion in the pools themselves. However, it is unlikely that 
there is a significant effect on the breakthrough curves as the transit time across the pools is of the order of a few hours and observation of the tracer within the pools showed that there were no stagnant areas. Further processes that might enhance dispersion and tracer loss are sorption onto sediments in the Palaeogene and the Chalk, and photochemical decay in the pools: these processes are currently considered of low significance but further work is required to quantify their effects.

The results from the Smithcroft Copse tracer test also provide some evidence that at least some sections of the pathway are discrete and isolated from other groundwaters because although Ingle and Jewells springs are directly in line between the sink and the Blue Pool, no tracer was detected at either. Comparison of the background fluorescence at the monitoring sites also suggests discrete groundwater sources in the vicinity of the Blue Pool. Background fluorescence occurs in springs and rivers from dissolved organic matter, in particular where springs and rivers receive sewage or agricultural effluent (Baker, 2002; Baker et al., 2003). Variations in background fluorescence between sites can give a rough guide to groundwater characterisation. The very low background fluorescence at the borehole (Table 2) suggests a different groundwater source from that of the Blue Pool, and implies that there is little connectivity between fractures and fissures intercepted in the borehole and the conduit system.

\subsection{Groundwater flow and tracer transport in Zones 2 and 3}

A single tracer test has been reported from the equivalent of Zone 2 from a soakaway in the Chalk, around $4 \mathrm{~km}$ from the Palaeogene margin at Bricket Wood in Hertfordshire (Price et al. 1992). Although tracer injection was not into a surface karst feature, velocities of $2 \mathrm{~km} /$ day proved rapid groundwater flow. Very low recoveries of $<0.01 \%$ imply a much higher degree of attenuation than is seen in Zone 1. There have been no tracer tests from Zone 3 areas in unglaciated Chalk, but unpublished results from the formerly glaciated Chalk aquifer in East Anglia indicate velocities $\sim 0.1 \mathrm{~km} /$ day over distances of up to $1.5 \mathrm{~km}$. Attenuation was extremely great, as in the test in Zone 2 by Price et al., (1992). The high attenuation in both zones probably reflects flow in fractures and fissures with relatively small apertures from which tracer would be lost by diffusion into the Chalk matrix. However, the frequency of rapid groundwater flow through karst conduits in both Zones 2 and 3 is currently poorly understood. It is probable that the occurrence of karst conduits decreases with distance from the Palaeogene margin. However, the Palaeogene once covered these areas of the Chalk, and depending upon how quickly erosion caused the edge of the former cover to retreat down-dip, conduit systems fed by stream sinks may have once been common in Zones 2 and 3. If the depth of conduit development exceeded the thickness of rock removed by erosion in the period since the Chalk was locally exposed, these conduits could still exist. The modern hydrogeological function of such relict conduits is unclear but they could potentially provide rapid flowpaths in the unsaturated zone (Figure 5).

\section{5) Conclusions}

Tracer testing in the Chalk has proved high groundwater velocities, indicating flow through open conduits. On the basis of the limited test results available, the presence of surface karst features often associated with the boundary between the Chalk and the overlying Palaeogene appear to be indicative of rapid groundwater flow in the sub-surface. Geomorphological mapping could therefore be a useful guide to 
vulnerability mapping; with high risk to groundwater in Zone 1 characterised by rapid groundwater flow and low attenuation, moderate risk in Zone 2 where there can be rapid groundwater flow, but higher attenuation, and perhaps progressively lower risk through Zone 3. However, more tracer testing, particularly in Zones 2 and 3 is required to test this hypothesis further.

Sub-surface karst in Zone 1 appears to be characterised by rapid groundwater flow through a combination of tubular conduits and more laterally extensive fissures. More conjecturally, the quantitative tracer test results from Smithcroft Copse to the Blue Pool suggest that the groundwater flowpath may comprise a complex anastomosing network of fractures, fissures, and perhaps dissolution tubules surrounding and well connected to a main conduit. Some tracer is transported rapidly through the main conduit causing the fast peak velocity, but there is also mechanical dispersion into the smaller voids where double porosity diffusion may occur. This high permeability conduit zone appears to be unconnected to other groundwaters, at least in the vicinity of Jewells and Ingle springs, where no tracer was detected. However tracer detection at multiple outlets (Atkinson and Smith 1974, and Harold 1937), sometimes over wide areas demonstrate that Chalk conduit systems can have extensive distributary elements which can connect with groundwater abstraction boreholes.

The Blue Pool is an example of a large Chalk spring with an unknown but probably small proportion of flow that has a very low residence time and is derived from stream sinks. A baseflow component with a much longer residence time is provided by water held in storage in the Chalk and possibly also in the Palaeogene. The Blue Pool catchment could be more accurately defined by further tracer tests from stream sinks to the north and west of the spring, which may also provide further insight into the nature of the groundwater flowpath, and the role of stream sinks in recharging the conduits and fissures that discharge at the Blue Pool.

\section{Acknowledgements}

This work is funded by Natural Environment Research Council grant NER/T/S/2001/00956. We thank Craig Hampton at the Environment Agency for discussion and assistance, and the landowners in the catchments for allowing access. This paper is published with the permission of the Executive Director, British Geological Survey (NERC). 


\section{References}

Atkinson T.C. and Smith D.I., 1974. Rapid groundwater flow in fissures in the Chalk: An example from South Hampshire. Quarterly Journal of Engineering Geology, 7, 197-205.

Baker, A., 2002. Fluorescence properties of some farm wastes: implications for water quality monitoring. Water Research, 36 (1), 189-195.

Baker A., Inverarity R., Charlton M. and Richmond S., 2003. Detecting river pollution using fluorescence spectrophotometry: a case study from Ouseburn, NE England. Environmental Pollution, 124 (1), 57-70.

Banks C., Davies C. and Davies W., 1995. The Chalk as a karstic aquifer: evidence from a tracer test at Stanford Dingley, Berkshire, UK. Quarterly Journal of Engineering Geology, 28, 31-38.

Barker J.A., 1982. Laplace transform solutions for solute transport in fissured aquifers. Adv. Water Resources, 5 (2), 98-104.

Barker J.A., 1991. Transport in fractured rock. In Applied Groundwater Hydrology, Downing and Wilkinson (Eds.). Oxford University Press 199-216.

Bloomfield J.P., 1995. Characterisation of hydrogeologically significant fracture distributions in the Chalk: an example from the Upper Chalk of southern England. Journal of Hydrology, 184 (3-4), 355-379.

Bradshaw J., Caiger N., Halpin M., Le Gear R., Pearce A., Pearman H., Reeve T. and Sowan P., 1991. Kent and East Sussex Underground. Kent Underground Research Group. Meresborough Books.

Edwards A.J., Hobbs S. and Smart P.L., 1991. Effects of quarry dewatering on a karstified limestone aquifer: A case study from the Mendip Hills, England. In: Proceedings of the third conference on hydrogeology, ecology, monitoring, and management of groundwater in karst terranes, National Water Well Association, 77, 92. 
Grapes T.R., Bradley C. and Petts G.E., 2005. Dynamics of river-aquifer interactions along a chalk stream: the River Lambourn, UK. Hydrol. Proc. 19 (10), 2035-2053.

Harold C., 1937. The flow and bacteriology of underground water in the Lee Valley. Metropolitan Water Board 32nd Annual Report, 89-99.

Lamont-Black J., 1995. The engineering classification of chalk with special reference to the origins of fracturing and dissolution. PhD Thesis, University of Brighton.

Lamont-Black J. and Mortimore R., 2000. Dissolution tubules: A new structure from the English Chalk. Zeitchrift für Geomorphologie, 44, 469-489.

Lowe, D.J., 1992. Chalk caves revisited. Cave Science, Transactions of the British Cave Research Association, 19, 55-58.

Macdonald A.M., Brewerton L. and Allen D.J., 1998. Evidence for rapid groundwater flow and karst type behaviour in the Chalk of Southern England. In: Groundwater pollution, aquifer recharge and vulnerability, Robins NS (Ed), Geological Society of London special publication No. 130, 95-106.

Price M., 1987. Fluid Flow in the Chalk of England. In: Fluid flow in sedimentary basins and aquifers, Goff, J.C. and Williams, B.P.J. (Eds). Geological Society Special Publication No 34, 141-156.

Price M., Atkinson T.C., Barker J.A., Wheeler D and Monkhouse R.A., 1992. A tracer study of the danger posed to a chalk aquifer by contaminated highway run-off. Proc. Instn. Civ. Engrs., Wat., Marit., \& Energy, 96, 9-18.

Rodet, J., 1985. Le développement du karst dans la craie de Normandie et ses consequences sur la protection des eaux souterraines. Annales de la Société Géologique de Belgique, T.108, 33-41.

Walsh P.T. and Ockenden A.C., 1982. Hydrogeological observations at the Water End swallow hole complex, North Mimms, Hertfordshire. Cave Science, Transactions of the British Cave Research Association, 9 (3),184-194

Waltham, A.C., 1975. Chalk caves in France. British Cave Research Association Bulletin No. 7 page 10.

Waltham, A.C., Simms, M.J., Farrant, A.R. and Goldie, H.S. 1997. Karst and Caves of Great Britain. Geological Conservation Review, Vol. 12. London Chapman and Hall. 


\section{List of Figures}

Figure 1: Flowing karstic conduit 150 to $200 \mathrm{~mm}$ diameter, Swanscombe Quarry, Kent, England

Figure 2: Relationship between Palaeogene cover and surface karst in the Pang and Lambourn catchments

Figure 3: Location of tracer injection sinks and monitoring points, River Pang

Figure 4: Tracer breakthrough at the Blue Pool

Figure 5: Schematic north-south cross section of Palaeogene retreat from Zone 2 to Zone 1

\section{List of tables}

Table 1: Results of tracer testing from Smithcroft Copse to the Blue Pool

Table 2: Background fluorescence ( $\mu \mathrm{g} / \mathrm{l})$ at sampling sites

Table 3: Flow data (1/s) obtained during the tracer testing 
Figure 1

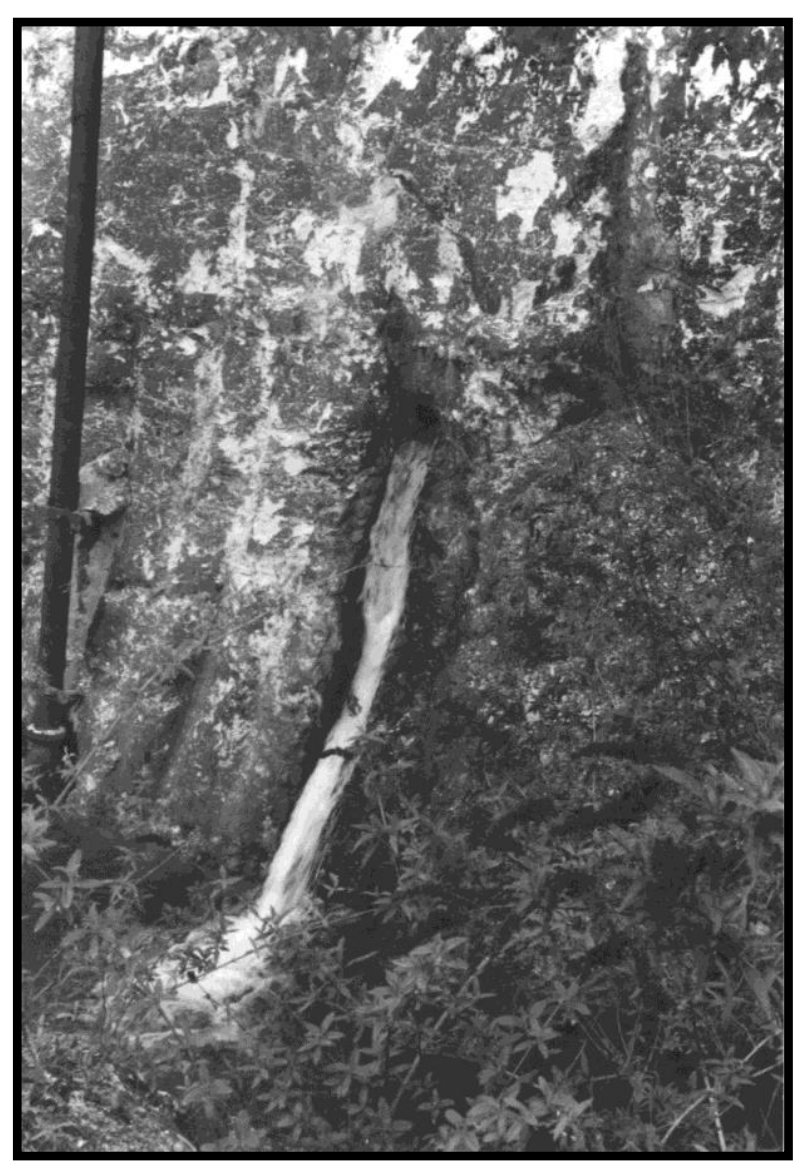


Figure 2

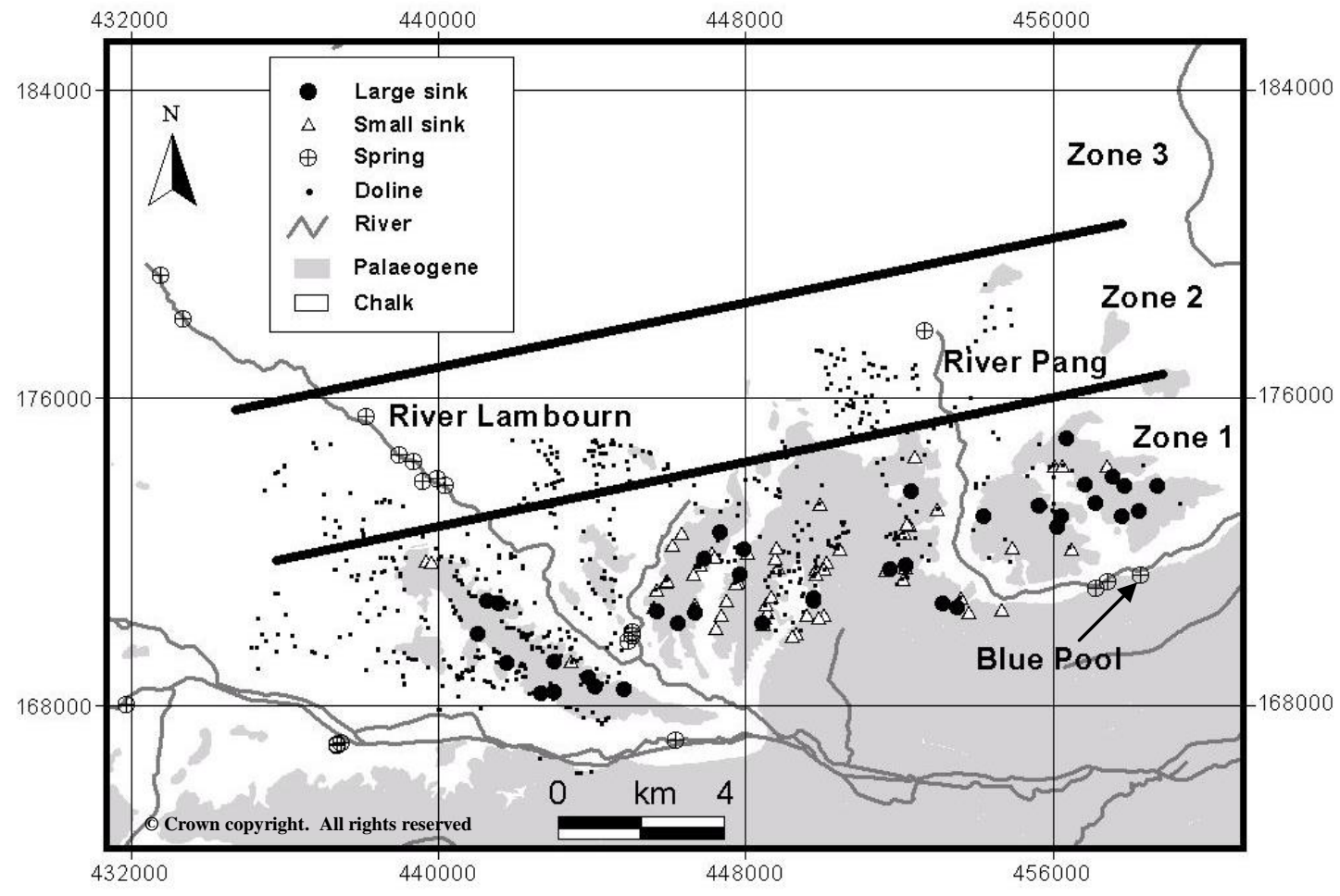


Figure 3

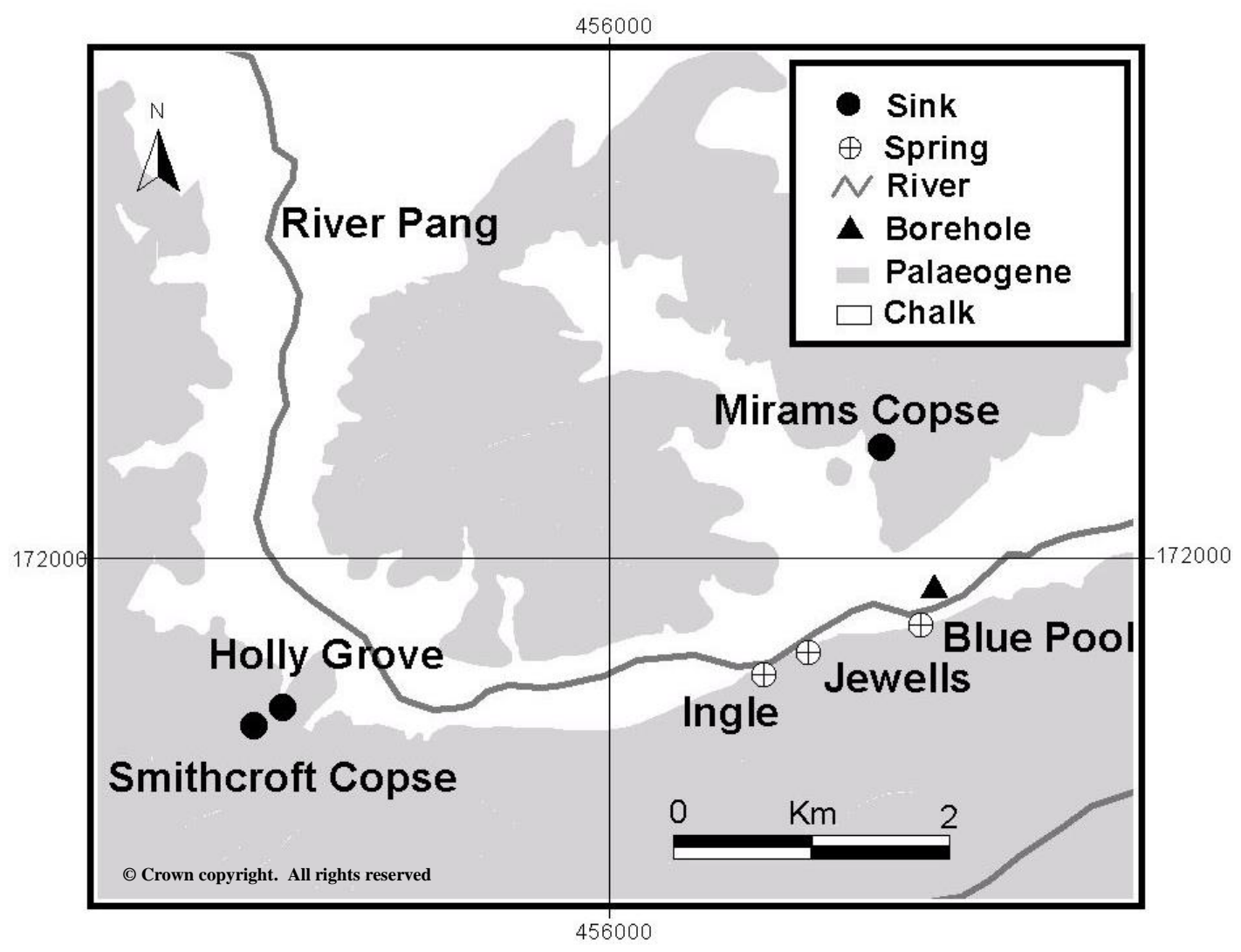


Figure 4

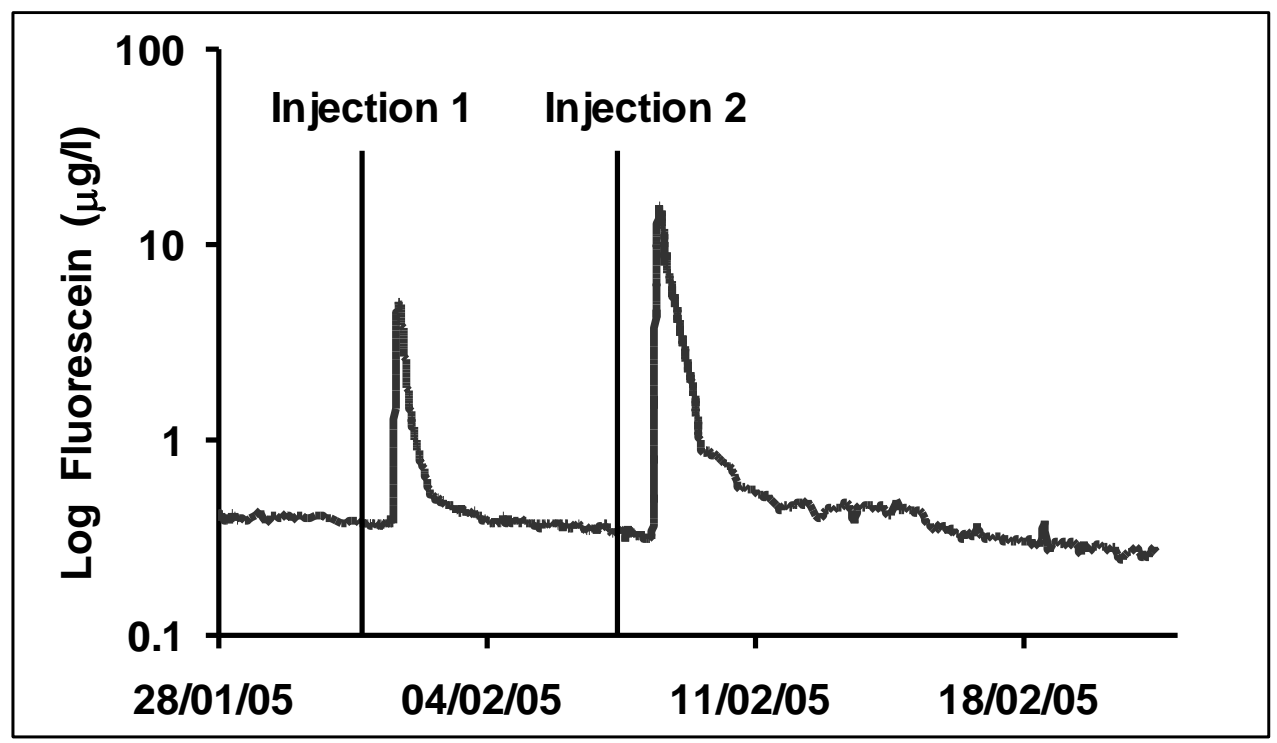


Figure 5

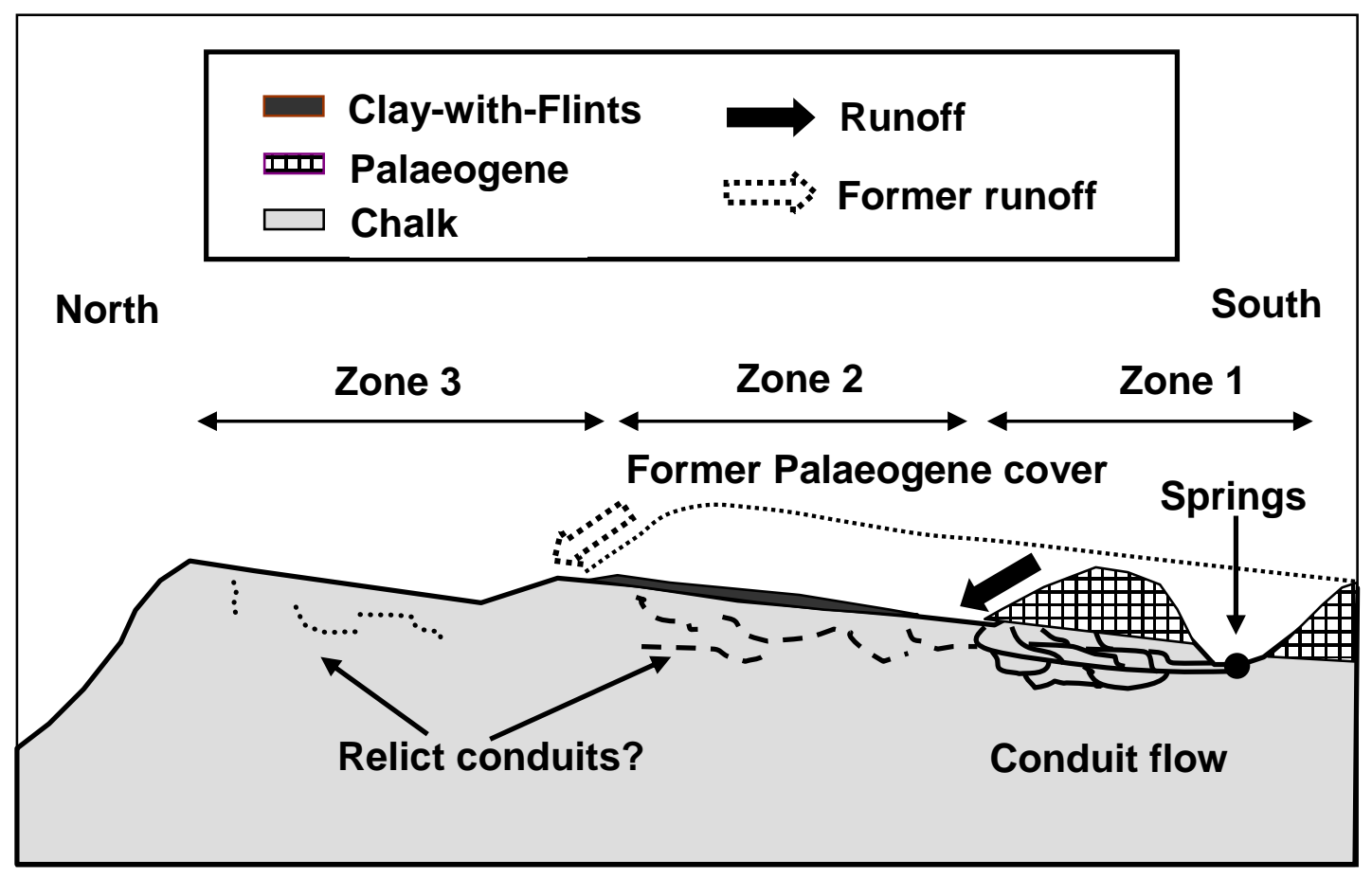


Table 1

\begin{tabular}{ccccc}
\hline Injection & Blue Pool Flow (l/s) & Time to Peak & Velocity $(\mathbf{k m} / \mathbf{d})$ & Recovery (\%) \\
\hline $31 / 01 / 05$ & 209 (during peak) & 24 hours & 5.12 & 25.5 \\
$07 / 02 / 05$ & 197 (during peak) & 26 hours & 4.71 & 21.7 \\
\hline
\end{tabular}

Table 2

\begin{tabular}{ccccc}
\hline $\begin{array}{c}\text { Downstream } \\
\text { River Pang }\end{array}$ & Blue Pool outlet & Jewells & Ingle & Borehole \\
\hline 0.5 & 0.35 & 0.18 & 0.2 & 0.06 \\
\hline
\end{tabular}

Table 3

\begin{tabular}{ccccc}
\hline Date & Blue Pool outlet & Jewells & Ingle & Downstream R Pang \\
\hline $04 / 11 / 04$ & & & & 424 \\
$03 / 02 / 05$ & 209 & 20 & & 335 \\
$07 / 02 / 05$ & 197 & & 30 & 335 \\
$09 / 02 / 05$ & 185 & & & \\
$10 / 02 / 05$ & 194 & & & \\
$15 / 02 / 05$ & 196 & & & \\
\hline
\end{tabular}

